\title{
IAMJ
}

INTERNATIONAL

AYURVEDIC

MEDICAL JOURNAL

\section{A REVIEW ARTICLE ON MASANUMASIK GARBHINI PARICHARYA}

\author{
Deepak Kumar ${ }^{1}$, Pasupati Nath ${ }^{2}$, Arti Alankar Rajhans ${ }^{3}$, Subhash Upadhayay ${ }^{4}$ \\ ${ }^{1}$ PG Scholar, ${ }^{2}$ Assistant. Professor, ${ }^{3}$ Associate Professor, ${ }^{4}$ Professor \& H.O.D. \\ Dept. of Sharir Rachana, Sriganganagar College of Ayurvedic Science \& Hospital, Tantia University, \\ Sriganganagar - 335001, India
}

Corresponding Author: drsherawat.1031@gmail.com

\section{https://doi.org/10.46607/iamj10p4062020}

(Published online: September 2020)

Open Access

(C) International Ayurvedic Medical Journal, India 2020

Article Received: 18/09/2020 - Peer Reviewed: 22/09/2020 - Accepted for Publication: 24/09/2020

\section{Check for updates}

\section{ABSTRACT}

Ayurveda considers food to be the best source of nourishment as well as medication for the pregnant woman. The nine monthly diets are singularly unique to Ayurveda. It changes in accordance with the growth of the fetus in the womb and at the same time ensures health of the mother. The woman is considered as one of the most essential factors for the continuity of the human race. During Garbhavastha, she experiences lots of anatomical as well as physiological changes at the level of Dosha, Dhatu and Mala. These changes are nothing but maternal adaptation to the increasing demand of the growing fetus. The Growth and development of fetus requires more nutrition from mother. This causes increased workload on the maternal Dhatus, so she needs extra nutrition during Garbhavastha. Ayurveda has suggested a very good protocol Masanumasik Garbhini Paricharya i.e. Ahara (diet), Vihara (lifestyle), Vichara (psychological aspect) to be followed during pregnancy with respect to each month. This article describes an Ayurveda perspective of Ahara Vihar W.S.R to Masanumasik Garbini Paricharya.

Keyword: Garbhini, Garbhini Paricharya, Aahar, Vihar, Vichara 


\section{INTRODUCTION}

Ayurveda is a science of life and basic principle of Ayurveda is Swasthasya Swasthya Rakshanam Athurasya Roga Prasamanam" (1).

To maintain Swasthya of pregnant lady Garbhini $\mathrm{Pa}$ richaya is most important. Fetus is dependent on mother for its nourishment and oxygen. The care of the pregnant lady reflects on the quality and health of the offspring. Health of the pregnant women is maintained through proper Garbhini Paricharya right from the conception till delivery. Garbhini Paricharya includes all aspects of care of pregnant lady like Ahar (diet), Vihar (exercise), Apathya (don'ts) Yoga and Meditation etc. Food is called life of living being. Even if drugs are introduced to a diseased person he cannot get cured without proper food. Hence food is called as great medicine. Food can be adjusted in such a fashion that it fulfils the need of body and brings about homeostatic condition ${ }^{(2)}$. Diseases of Garbhini are very difficult to treat ${ }^{(3)}$. The health of baby completely depends on mother therefore it is better to take care that pregnant lady is getting adequate care and nutritious and proper food so that she delivers a healthy baby without complications. This can be achieved with the help of Gabhini Parichaya. In the present review prime focus is given on monthly Regimen for Pregnant woman described in Ayurvedic classics so as to achieve healthy baby to healthy mother.

The classic Ayurveda mentioned Ahara and Vihara as tool for the management of pregnancy and for achieving above mentioned goal. Ahara and Vihara play significant role towards the health of pregnant women and development of fetus. The Ayurveda described special dietary counselling for pregnant women having other clinical symptoms such as obesity, diabetes, liver disease, hypertension, metabolic disease, intestinal disease and anorexia. Ayurveda mentioned specific Ahara and Vihara for pregnant women.

The care of pregnancy mainly involves:

1. Month wise dietary regimen (Masanumasika Pathya)

2. Consideration of activities and substances which may cause harm (Garbhopaghathakara bhavas)
3. Consideration of substances which are beneficial during pregnancy (Garbhasthapaka Dravyas)

Month wise Ahara Vihara as per Ayurveda during pregnancy

\section{For 1st month}

Milk processed in Shaliparana and Palasha twice a day. Ghee, sweet, cool liquid and light food stuffs.

\section{For 2nd month}

Medicated sweetened milk and cold liquid diet.

\section{For 3rd month}

Milk processed with Madhu and Ghee, Shasthishali, sweet, cold and liquid diet.

\section{For 4th month}

Milk and butter (approx. two Tola), curd rice specially Shasthishali rice and meat.

\section{For 5th month}

Ghee, rice with milk, Khichadi and Payasa.

\section{For 6th month}

Medicated ghee, Khichadi and sweetened curd.

\section{For 7th month}

Ghrita medicated with Vidarikandadi drugs for proper development of fetus and Ghritha Khanda.

\section{For 8th month}

Yavagu prepared in milk with ghee, Asthapana basti (Bala, Atibala) and Anuvasana Basti (use of Madhura Dravas).

\section{For 9th month}

Yoni Pichu, Anuvasana Basti and Vataghana Drava Yukta Snana; these all help for normal delivery. ${ }^{(4-10)}$ Ayurveda suggests use of nutrients and herbal medicines for nourishment and wellbeing of mother and fetus. Ayurveda prescribes balanced and nutritional diet during pregnancy period. The Ahara for pregnant women must be Hridya, Dravam, Madhuraprayam, Snigdham, Deepaniyam, and Samskritam. This type of balance diet during pregnancy boosts maternal health, fulfill needs of the growing fetus, improve lactation and offer normal delivery. ${ }^{(11,12)}$

\section{Aim and Objectives:}

1. To collect and analyze the Masanumasik Garbhini paricharya.

2. To study the role of Ahara Vihara in Masanumasik Garbhini Paricharya. 
The main aim of Ayurveda towards the care of pregnant women resides around three main objectives:

1. Paripurnatva (proper growth of the fetus and mother)

2. Anupaghata (non-complicated pregnancy)

3. Sukhaprasava (normal delivery)

Materials and Methods

Literature: Brihatrayee, all available Ayurvedic classics, Modern available texts, Magazines, Journals \& Research papers.

\section{Masanumasik Garbhini Paricharya}

Garbhavastha is a state in which all physiological functions are stimulated in order to meet demand of growing fetus. The growth and development of fetus need more nutrition from mother. This causes extra workload on maternal Dhatus so she needs extra nutrition during Garbhavastha. ${ }^{(13)}$ Charaka says that Garbhini is fit for the use of Bruhana (anabolic) therapy. Vagbhata suggested external (for preparing water for bathing or irrigation etc.) and internal (powder, cold percolation, decoction etc.) use of Jiwaniya group of drugs. Affectionate and good Behaviour of husband and servants helps in maintenance of pregnancy. Milk provides nourishment and stability to the fetus; meat helps in achievement of pregnancy, provides nourishment to the fetus, suppresses Vata of pregnant woman, meat soup is superb medicine for her. Yogaratnakara has enlisted following food stuffs beneficial for pregnant woman i.e. salt and Swastika rice, Mudga (green gram), wheat, flour of parched rice, butter, Ghruta, milk, Rasala (curd mixed with sugar and condiments), honey, sugar, jack-fruit, banana, fruit of Amalaki, Draksha, sour and sweet substances; anointment with cooling agents, musk, sandal and camphor; wearing of garlands; moonlight bath, massage, soft bed, cool air, anabolic or gratifying edibles, embracing beloved and other pleasing mode of life along with desired food.

The month wise Paricharya helps in proper development of fetus and gives health to mother. By following the timely regimen described gives benefits to, the mother and her body parts like abdomen, flanks, back and genital organs become Mrudu and Anulomana of Vayu occurs. The natural urges are expelled out easily, through their respective passages. The skin and nails become smooth and Garbhini attains high degree of Bala, Varna and Oja. All these factors contribute in the full development and delivery of a child with all qualities and health. Contrary to this, if a Garbhini does not follow the above said Paricharya that may result in many problems regarding health of both mother and fetus and also result in such complications which may need immediate attention. Our ancient Acharyas knew well that not only the food and environment play a vital role in the development of fetus but also maternal psychic impressions have their impact on a growing fetus. Hence, they have given equal importance to all factors.

Ayurveda has suggested a wholesome diet during the period of Garbhavastha. This result in fetal growth, maternal health and post-delivery lactation. In first month Garbha is in Kalal form and it get nutrition by Upsnehana. So Garbhini should take proper diet to make balance of Rasa and Rakta Dhatu. In second month Garbha start to take compact form with limb and head. Madhur Rasa Dravyas provide nutrition to Garbha. In third month, different body parts start to differentiate, heartbeat initiate with sensory and motor reaction. In this period Garbha express its desire through mother's craving. Fulfilling this craving is helpful for proper growth. If one neglects Vata get vitiated and deform Garbha. ${ }^{(14)}$ During the first three months fetal growth organ are only in stage of formation and maternal Rasa and Rakta Dhatu are used for nourishing the uterine bed. Hence more Jaleeya [liquid] substances are advocated. In fourth and fifth month Mamsa Dhatu gets nourished in Garbha, so Garbhini is advised to eat Jangal Mamsa. In sixth month, fatty tissues of Garbha is formed. In Second trimester, the formation of fetal Dhatu starts and thus Ayurved suggested diet to boost this Dhatu formation which is the origin of the next chain of Dhatu, in the fifth month Rakta [blood] and Mamsa [muscle] are formed, in sixth month Meda Dhatu is formed. In seventh month, most of Garbhini suffers from oedema of feet. This may be due to increase pressure on lower limb and water retention. To get relief from this Gokshur is advised as it is good diuretic. Around the 
seventh month fetal growth is practically complete after which only refining work remains. In seventh month Madhur Ksheer and Ghrit is advised which help in proper development of foetus. In last trimester Yavagu is advised and in nine-month Asthapana, Anuwasan Basti is advised for Sukhaprasav. Following Garbhini Paricharya the woman remains healthy and delivers the child possessing good health, energy, voice, compactness and much superior to other family members. ${ }^{(15)}$

\section{DISCUSSION}

From above literature it is clear that milk and drugs of Madhura group have been advised for entire pregnancy period. Milk is a wholesome diet. It provides nutrition and stability to the fetus. The drugs of Madhura group are having anabolic property. Hence, the use of these drugs will help in maintenance of proper health of Garbhini and development of fetus. During 1st trimester of pregnancy, most women have the complaints of nausea and vomiting. So, they cannot take proper diet. Use of cold, sweet, liquid diet and milk will prevent dehydration and supply required nourishment. From 4th month onwards, muscular tissues of fetus grow sufficiently. According to the principle Mamsa Dhatu gets well-nourished with its Svayoni Vardhana Dravyas i.e. Jangala Mamsa. Hence, Sushruta might advise the pregnant woman to take Jangala Mamsa. Kashyapa says that the meat soup which is taken by pregnant woman not only helps in achievement of pregnancy, but also provides nourishment to the fetus. It also suppresses Vata of pregnant woman. By the end of 2nd trimester, most of the pregnant women suffer from such complications of water accumulation as oedema over feet; use of Gokshura may prevent these disturbances, as it is a good diuretic. Yavagu, is advised by Charaka in 8th month, the Garbhini remains free from diseases and delivers the child possessing best health, energy, complexion, voice, compactness of the body. Asthapana and Anuvasana Bastis help in Shodhan of Pureesha and Anulomana of Vayu which in turn leads to Sukha and Nirupadrava Prasava. So, the Garbhini who follows the above said Upakramas becomes Snigdha, gains strength and delivers normally and easily without any complication. Concept of Garbhini $\mathrm{Pa}$ richarya is programmed with an objective of the birth of "Shreshtamapatyam". The benefits of these entire regimen, ensures the procurement of a "Supraja" (16)

\section{CONCLUSION}

In Ayurveda a scientific protocol is given for Garbhini Paricharya. It should be followed by Garbhini as it is necessary for formation of qualitative Rasa Dhatu which nourishes Garbhini, her Garbha and helpful in production of milk. It is also helpful for proper functioning of Vayu (Apana Vayu) which is necessary for Sukhaprasav.

The consideration of Masanumashika Paricharya for woman from first month to the ninth month of pregnancy play significant role towards the health of mother and new-born. The consideration of concept of Ahara and Vihara helps as follow:

1. Softening of Apara, pelvis and waist

2. Vataanulomana for the normal delivery

3. Detoxification

4. Promotion of strength

Ayurveda prescribed specific Ahara and Vihara for pregnancy period, milk along with liquid diet for first trimester of pregnancy to avoid malnutrition. Basti is also helpful in last period of pregnancy to strengthen myometrium and also boost labour functioning.

\section{REFERENCES}

1. Reddy Sudhaka. Comprehensive guide to Swasthvritta. Varanasi, Chaukhamba Sanskrit Pratishthan, 2006, p.114

2. Dhargalkar Nandini. A textbook of Physiology, Varanasi, Chaukhamba Sanskrit Series Office, 2008, p.7

3. Tiwari P V. Ayurvediya Prasuti tantra evum Striroga Part 1, 2nd Edition, Varanasi, Chaukhamba Oriental, 2009, p. 242-243.

4. Acharya Charaka, Charaka Samhita with Vidyotini Hindi Commentary by Acharya Kasinath Shastri and Gorakhnath Chaturvedi, Sharira Sthana 8/48, 16th edition, Chaukhambha Bharati Academy, 1989; 951.

5. Acharya Vagbhata, Ashtanga Sangraha edited by S.P. Sharma, Sharira Sthana 3/38, 1st edition, Chaukhambha Sanskrit Series Office, Varanasi, 2006; 285. 
6. Tiwari P.V., Ayurvediya Prasuti tantra and Stri Roga, 1st Part, 2nd edition, Chaukhambha Orientalia, Varanasi, 1999; 551.

7. Yadavji Trikamji editor, Commentary: Vidyotini Hindi Commentary of Acharya Kasinath Shastri and Gorkhnath Chaturvedi on Charaka Samhita of Chara$k a$, Sharira Sthana, chapter 8, verse no. 32, 22nd edition, Varanasi: Chaukhambha Bharati Academy, 1996; 937.

8. Vagbhata, Commentary, Indu Commentary of Vaidya Anant Damodar Athavale on Astanga Sangraha, Sharira Sthana, chapter 3, verse no.2, 1st edition, Pune, Shree Mada Atreya Prakashana, 1980; 279.

9. Vagbhata, Commentary, Indu Commentary of Vaidya Anant Damodar Athavale on Astanga Sangraha, Sharira Sthana, chapter 3, verse no.3, 1st edition, Pune, Shree Mada Atreya Prakashana, 1980; 279.

10. Harita, Commentary, Nirmala Hindi Commentary of Acharya Ramavalamba Shastri on Harita Samhita, Tritiya Sthana Chapter 49, verse no.2, 1st edition, Varanasi: Prachya Prakashana, 1985; 86.

11. Sushruta Samhita by Ambika Dutta shastri Sharir Sthan 2 verse no.35 Chaukhambha Samskrit Sansthan Varanasi, 2007; 15.

12. Sushruta samhita, Yadavji Trikramji with Nimbandhsamgrah commentary of Dulhana and Nyaychandrika Panjika of Gayadas 4thed. Sharirsthan 10 verse no.4 chaukhambha Orientalia Varanasi, 1992, 387.

13. Umarkar S, Vyas D. Status Of Sharir Dosha in Garbhini with Special Reference to Raktalpata-An Observational Study. International Ayurvedic Medical Journal. 2017 April.

14. Naga SLC. Concept Of Garbhini Paricharya. International Ayurvedic Medical Journal. 2013 Nov-Dec. I(6).

15. Anjumani Deka1 KK. Garbhini Paricharya and Its Clinical Importance. International Ayurvedic Medical journal. 2017 May.

16. N VB. An Illustration of The Garbhini Paricharya As Explained In. International Ayurvedic Medical Journal. 2017 June.

\section{Source of Support: Nil \\ Conflict of Interest: None Declared \\ How to cite this URL: Deepak Kumar et al: A Review Article on Masanumasik Garbhini Paricharya. International Ayurvedic Medical Journal \{online\} 2020 \{cited September, 2020\} Available from: http://www.iamj.in/posts/images/upload/2510_2514.pdf}

